\title{
Modeling of River Channel Shading as a Factor for Changes in Hydromorphological Conditions of Small Lowland Rivers
}

\author{
Tomasz Kałuża ${ }^{1}{ }^{(}$, Mariusz Sojka ${ }^{2}{ }^{(}$, Rafał Wróżyński ${ }^{2}{ }^{\circledR}$, Joanna Jaskuła ${ }^{2}{ }^{\circledR}$, \\ Stanisław Zaborowski ${ }^{1}$ and Mateusz Hämmerling ${ }^{1, * \mathbb{D}}$ \\ 1 Department of Hydraulic and Sanitary Engineering, Poznań University of Life Sciences, Piątkowska 94, \\ 60-649 Poznań, Poland; tomasz.kaluza@up.poznan.pl (T.K.); zaborowski.stanislaw@gmail.com (S.Z.) \\ 2 Institute of Land Improvement, Environment Development and Geodesy, Poznań University of Life Sciences, \\ Piatkowska 94, 60-649 Poznań, Poland; mariusz.sojka@up.poznan.pl (M.S.); \\ rafal.wrozynski@up.poznan.pl (R.W.); joanna.jaskula@up.poznan.pl (J.J.) \\ * Correspondence: mateusz.hammerling@up.poznan.pl; Tel.: +48-61-846-6589
}

Received: 6 December 2019; Accepted: 12 February 2020; Published: 13 February 2020

\begin{abstract}
The ecological water quality in rivers and streams is influenced both by the morphological factors (within the watercourse channel and by the dynamic factors associated with flow), as well as biological factors (connected with the flora and fauna characteristic of its specific area). This paper presents an analysis of the effect of river channel shading by trees and shrubs on hydromorphological changes in a selected reach of the Wełna River, Poland. The analysis was conducted on two adjacent cross-sections (one in a reach lined with trees, the other in an open area with no tree or shrub vegetation). Data were collected during field surveys in the years 2014 and 2019. According to the Water Framework Directive, the Wełna River represents a watercourse with small and average-sized watershed areas, with sand being the dominant substrate of the river bottom. Flow volume, distributions of velocity in the sections, as well as substrate grain-size characteristics and river bottom morphology, were determined based on field measurements. In the study, the leaf area index (LAI) of vegetation was measured in the reach lined with trees, while the number and species composition of macrophytes were determined in the investigated river reaches. Moreover, a digital surface model (DSM) and Geoinformation Information System GIS tools were used to illustrate variability in shading within the tree-lined reach. The DSM model was based on Light Detection and Ranging (LIDAR) data. The results of this study enable us to establish the relationship between river shading by vegetation covering the bank zone, and changes in hydromorphological parameters of the river channel.
\end{abstract}

Keywords: small lowland rivers; flow conditions; riverbed shading; shading model; hydromorphological changes; LAI; LIDAR

\section{Introduction}

Present-day requirements imposed on river and canal maintenance are closely related to the assurance of good ecological water quality and adequate condition of the semiaquatic ecosystem comprising the river and its valley [1,2]. The ecological water quality of rivers and streams is affected both by the hydromorphological conditions of the watercourse channel and by biological factors, related to the flora and fauna characteristic of its specific area [3-5].

In turn, the condition of a semiaquatic ecosystem is connected with the spatial system of the watercourse and with the biological equilibrium within the valley [6]. This should be reflected in the approach to river maintenance, particularly the adopted flood control system [7]. Presently binding guidelines for the maintenance of rivers classified as natural (or semi-natural) not only 
accept vegetation within their channel cross-section, but also assign them numerous protective and environmental functions [8-10]. This relates to the comprehensive, modern understanding of water management, which for planned engineering measures requires an environmental impact analysis following the principles of sustainable development [1].

The legal framework for works in rivers is outlined, among others, in the Water Framework Directive. Recently, the European Union has enacted the Water Framework Directive with the aim of securing and, where possible, improving the ecological status of watercourses throughout all Member States. The fundamental legal issues are set out in the Acts of the European Parliament, which define the rights and responsibilities of all parties with respect to rivers and streams [1-3]. In addition, in many countries separate measures are being implemented to improve the natural condition of rivers (e.g. in the USA, Canada, Norway) [6,9].

The above-mentioned conditions need to be reconciled with economic concerns imposed by the analysis of efficiency for water management investments. These include primarily flood control measures, limiting the highest water stages and flows, as well as actions ensuring good ecological status of surface waters at the lowest water stages and flows [1]. Thus, these requirements jointly result in the need to precisely estimate hydraulic parameters of flow in rivers and canals [11]. It is the accuracy of assessment that determines the decision to adopt a specific solution, as well as the technology required to implement it. Referring this aspect to river hydraulics, it may be treated as an evaluation of river channel capacity under specific geometric parameters, river regulation infrastructure, and vegetation growth [12]. This pertains particularly to overgrown river channels and conditions found in rivers with floodplains.

Growth of aquatic vegetation is the main factor in determining flow conditions in small rivers and canals [9]. Aquatic vegetation in channel sections causes an increase in flow resistance. It is a potential source of flood risk and resulting losses [13], when heavy rains in the vegetation period may lead to flash floods in small watercourses, whose flow capacity is reduced as a result of vegetation overgrowth [12]. This in turn leads to a decrease in channel flow capacity. Growth of aquatic vegetation is the primary biological process affecting flow conditions. This growth is modified by hydraulic and geometric parameters of the channel, as well as other physical factors (light, temperature, changes in water levels) along with chemical, edaphic, and biotic factors [14,15]. However, the main factor initiating the whole cascade of resulting phenomena is connected with sunlight, which, in association with biogenic compounds availability, limits productivity of aquatic ecosystems [16-18].

Growth of aquatic plants (macrophytes) depends on the action of various ecological factors. The most important of these include light and heat, water quality [19], pH, water hardness, water current intensity [20], and bed substrate [21]. The response of aquatic plants to ecological factors is very strong, which has contributed to their utilization in the evaluation of the environmental condition. In most European countries, systems based on macrophytes are extensively applied to assess water status [22]. The value of macrophytes as bioindicators is related to their capacity to characterize more permanent changes in habitat characteristics [19].

Growth of aquatic plants is strongly dependent on light availability [23]; thus, all changes in water transparency lead to changes in the structure of plant communities, vegetation density, and depth of plant growth $[24,25]$. The maximum increase in biomass of aquatic vegetation is observed under particularly advantageous growth conditions, including insolation [26,27]. The light factor determines not only biomass of aquatic plants, but also their structure, as an increase in insolation results in the development of plant organization. Additionally, the light factor in the water affects growing plants through modification of water temperatures $[27,28]$.

Numerous studies indicate that an important factor differentiating lighting conditions in watercourses is the vegetation-growing process on their banks, particularly forest and shrub communities [29]. In the case of small and medium-sized rivers flowing under the forest tree canopy, the amount of light reaching the water surface is several to several dozen percent lower than in rivers flowing through open areas. Such a situation may result in almost complete elimination of 
aquatic plants $[6,30,31]$. In other countries, the close dependence of aquatic plants on light conditions has already been used in practice to reduce excessive river channel vegetation overgrowth [18]. It has been suggested to increase shading of rivers in order to limit growth of common species of submerged plants [25]. This method has also been proposed to control excessive spread of invasive species in watercourses [24].

Trees and shrubs are natural landscape components in river valleys [32]. Factors affecting the richness of vegetation surrounding the channels and floodplains of lowland rivers include much slower water flow velocity, a greater width of the floodplain valley as well as river meandering and oxbow lake cutoff. The character of vegetation in the immediate vicinity of a watercourse channel and floodplains depends on the type of land use, groundwater levels, and frequency of flooding [12]. Typically, the area not utilized agriculturally is overgrown with floodplain forests. The areas with non-forest vegetation are usually various types of meadows and pastures, while in more moist locations, they are sedge rushes or fens [33]. Vegetation growing on riverbanks and floodplains has a considerable modifying effect on flow conditions. Apart from the obvious effect of direct factors on flow resistance during high flows (e.g. debris, bottom deposits, local obstacles) an essential role is also played by indirect factors, e.g. shading of the river channel and inhibition of aquatic vegetation growth. These changes are also reflected in river channel hydromorphology and the distribution of flow velocities [13].

When modeling flows in natural river channels, it is necessary to consider the effect of vegetation on flow resistance [34]. A problem typically found in vegetation-covered areas is related to the different flow dynamics compared to the dynamics of a stream free from vegetation. Velocities and depth gradients are then much smaller. This is naturally reflected in the dynamics of debris transport and hydromorphological changes in the watercourse channel $[5,34,35]$.

In order to determine the shading area, the location of trees within the riverbank zone needs to be described. Energy reaching the ground in a given spot depends on the position of the sun, insolation time, and cloud cover. Due to the continuously changing cloud cover, the input energy fluctuates considerably, and the changes may be detected only through precise measurements. The weather service reports mean monthly diurnal total solar radiation for various weather stations. This facilitates the development of an average annual model for the area covered by a given station. Based on the available data, Rickert [36] proposed a procedure to calculate the effect of shading on macrophyte growth. Data include photosynthetically active radiation (PAR) reaching the water surface and the rest of the radiation, which may be expected in the river channel at various turbidity levels based on total radiation in $\%$ or expressed in $\mathrm{W} / \mathrm{m}^{2}$. This method is relatively labor-intensive and includes the need for analyses of individual hourly sequences. At a tree height of, e.g., $10 \mathrm{~m}$, this is equivalent to shade range of $8 \mathrm{~m}$ in length. Solar radiation reaching the water surface is partly reflected and partly intercepted. The percentage of solar light reflection depends on factors such as angle of incidence (which then depends on latitude end land relief), wavelength, and land structure. The smaller the angle of incidence is, the greater is the amount of light which is reflected.

Variation in solar radiation is a fundamental to control most processes on the Earth. The solar radiation reaching the water surface is controlled by location (latitude, longitude elevation), season, atmospheric conditions, topography, and vegetation. Shading is a key parameter due to the control on the amount of direct radiation reaching the water surface. The factors influencing the fraction of solar radiation reaching the water surface can be taken into account by using tools and models working in a GIS environment. Nowadays calculations and analyses are carried out in different scales on the basis of data with different spatial resolution and type. Increasingly often high-resolution LIDAR data and GIS tools are used in shading analyses or assessments of incoming radiation reaching surface water bodies [37-40].

LIDAR data provide information on riparian attributes related to elevation, biomass overhanging the river, and vertical tree structure. In addition, high-resolution products generated by LIDAR data processing, such as the digital surface model (DSM) and digital elevation model (DEM), are used [41]. Bachiller-Jareno et al. [42] presented a methodology to estimate tree height and canopy extent, and 
a model that simulates the position of the sun across the sky for hourly or sub-hourly intervals to calculate the daily shade over the river surface. In addition, Loicq et al. [40] described the use of a spatially explicit method applying LIDAR-derived data to compute riparian shading based on direct and diffuse solar radiation. Karrasch and Hunger [41] demonstrated that during shading modeling based on DSM and DEM the illumination of the water body is underestimated, while shading is overestimated. In the United Kingdom, the Environment Agency (EA) has developed catchment 'shade maps' for every catchment managed under the Water Framework Directive in England and Wales [43].

The aim of this study was to determine the effect of vegetation growing on the Wełna riverbanks on changes in flow conditions within a relatively short river reach. Analyses were conducted from July to August.

\section{Materials and Methods}

Field studies were conducted in the years 2014 and 2019 on the Welna River, located in the belt of central European lowlands (Figure 1a). The Wełna River is a right bank tributary of the Warta River (ranking third in Poland in terms of river size). The Wełna River is $118 \mathrm{~km}$ in length, and its catchment area is $2621 \mathrm{~km}^{2}$. It flows from a lake located $10 \mathrm{~km}$ north-east of the town of Gniezno. Analyses were conducted on a selected river reach of $250 \mathrm{~m}$ in length, situated near the town of Coton. The study object is between a tree-covered area and an area with no tree or shrub cover, no water bodies, and no hydraulic structures, and there is no inflow from another watercourse. The investigated cross-sections no. 1 and 2 were shown on Figure 1a. In this way, any potential effect on disturbance of flow between the investigated cross-sections was eliminated (Figure 1b, Figure 1c).

a)

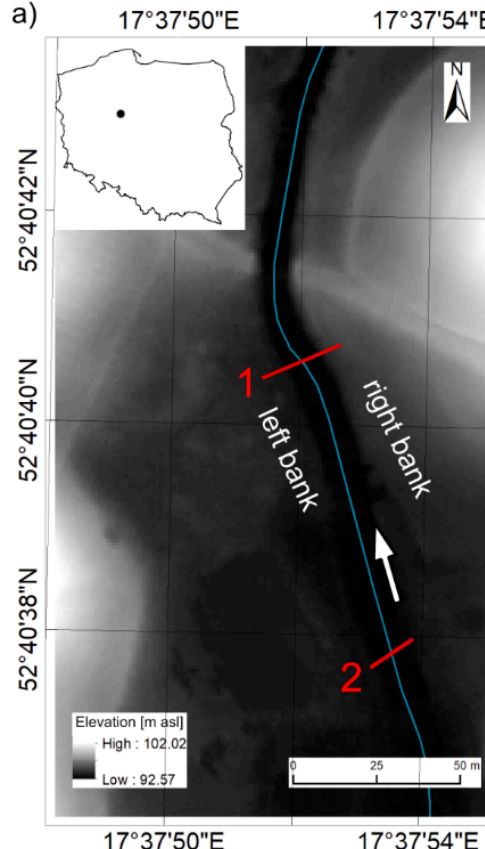

b)

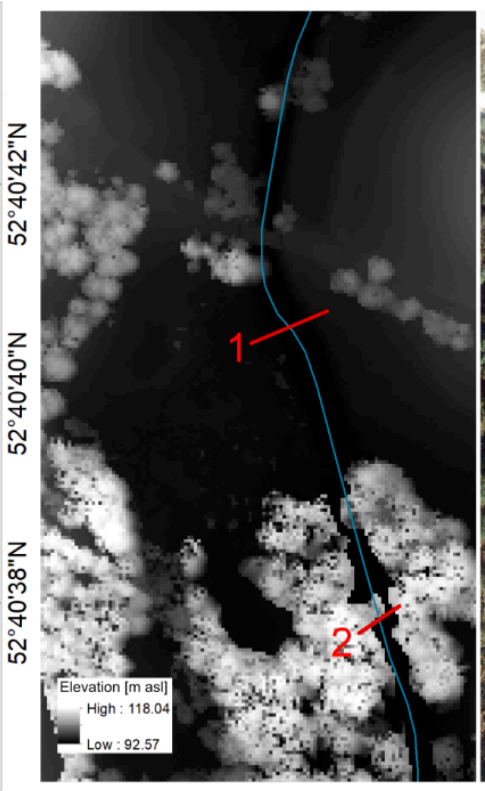

c)

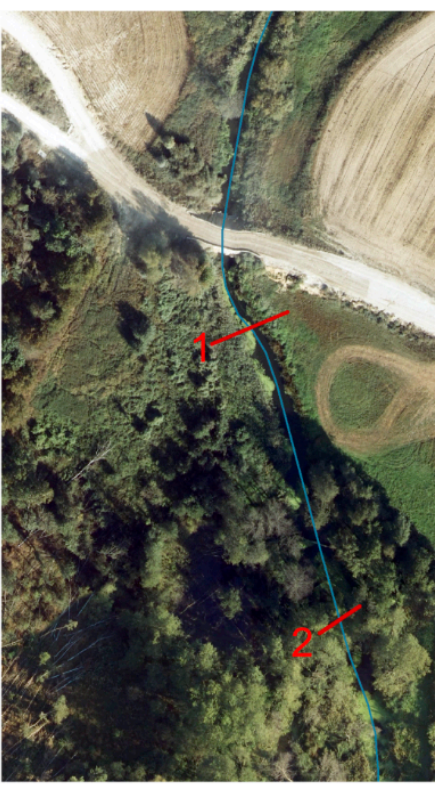

Figure 1. Location of the studied site in: (a) the digital elevation model (DEM), (b) the digital surface model (DSM), and (c) an aerial photograph.

Field measurements consisted of the assessment of watercourse hydrometric parameters. Within this study, the leaf area index (LAI) was also determined for vegetation in a tree-lined river reach, while the number and species composition of macrophytes found in the investigated river cross-sections were recorded [44]. Based on field measurements, the volume of flow and velocity distributions in cross-sections were determined along with the substrate grain-size characteristics and river bottom morphology. Moreover, a model was constructed to illustrate variability in the shade range within 
a river reach lined with trees. The shading analysis was based on DEM and a DSM developed on airborne LIDAR data. The results of this study enable us to establish the relationship between river shading by vegetation covering the bank zone and changes in the hydromorphological parameters of the river channel.

Based on LIDAR data, a DEM of the investigated river reach was developed (Figure 1a), while the location of trees was given in the DSM (Figure 1b). The current vegetation status in the analyzed Wełna River reach is presented in an aerial photograph (Figure 1c). Based on the forest stand description and a forest map, on the right bank of the river reach there is a forest subcompartment of 0.17 ha. Black alder (Alnus glutinosa) is the dominant species. The stand is approximately 70 years old. Common sallow (Salix cinerea) is the shrub species found in that area. In turn, a forest subcompartment of 7.7 ha is located on the left bank of the river. That subcompartment is a belt of swamps adjacent to the river at a length of approximately $50 \mathrm{~m}$.

Another subcompartment of 12.35 ha is located farther from the riverbank. It is a mixed forest with the predominance of oak (Quercus L.) and pine (Pinus sylvestris L.). Two measurement cross-sections were established in the selected river reach. Cross-section 1 was situated in a location with no trees or shrubs, while cross-section 2 was located in a site with banks lined with trees and shrubs. The distance between cross-section 1 and cross-section 2 is $93 \mathrm{~m}$. The locations of the cross-sections are marked in the presented maps (Figure 1). Figure 2 gives available aerial photographs of the investigated Wełna River in the years 2009-2019. They show an unchanged status of tree cover in this river reach.

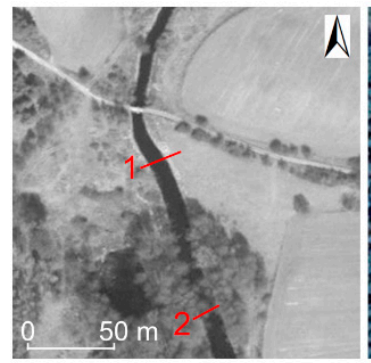

14.04.2009

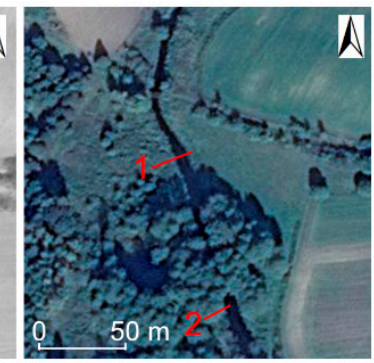

01.10 .2013

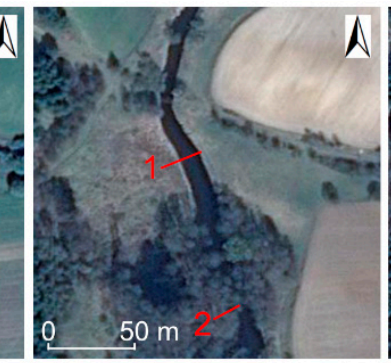

06.04.2014

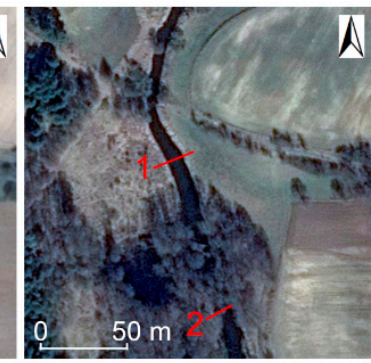

26.03.2017

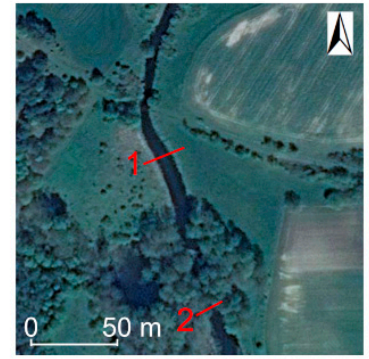

12.05.2017

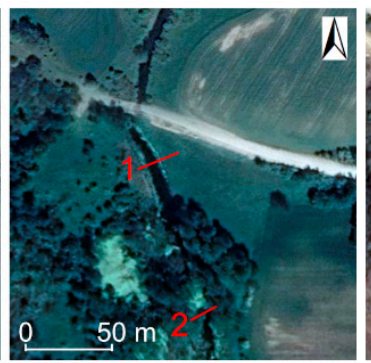

28.05.2017

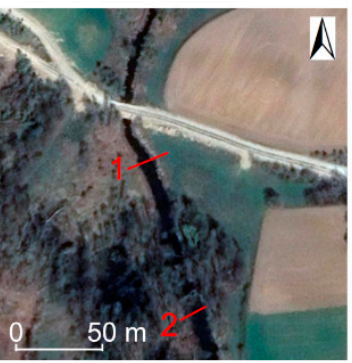

08.04.2019

Figure 2. Changes of land cover and shading of the watercourse in different periods and years (images obtained from GoogleEarthPro).

Flow measurements were taken in the individual cross-sections. For this purpose, a miniature ADCP StreamPro stream flow meter was used. The ADCP StreamPro instrument measures distributions of velocity, discharge intensity, and river bottom geometry. It operates based on the emission of acoustic signals.

Waves reach suspensions floating in water and are reflected by them, as a result returning to the emitter. The instrument processes thus obtained data and next determined the hydraulic parameters of discharge in the river bed. Analyses of river channel geometry consisted in measurements of the location and ordinates of points on the riverbanks and the river bottom using a GPS real-time kinematic (RTK) device accurate to $\pm 3 \mathrm{~mm}$ for vertical measurements. 
In order to determine the sediment composition analyses were conducted on the material collected from the river bottom. The grain-size distribution was analyzed using the sieve method according to the PN-B-00481:1988 (Polish standard) guidelines. To determine the grain-size composition, dried and ground samples were passed through a set of sieves $(0.063,0.125,0.25,0.5,1.0,2.0,3.15,4.0,6.0,8.0$, $10.0,16.0 \mathrm{~mm}$ ). Samples were dried in $105-110^{\circ} \mathrm{C}$. In order to determine organic matter content, the dried samples were precisely weighed accurate to $0.01 \mathrm{~g}$. Next, they were again subjected to heat-they were incinerated $\left(600-800^{\circ} \mathrm{C}\right)$ in a furnace. In this way the weight of the prepared samples made it possible to determine the content of organic matter. Samples were sieved again. Thus, the contents of minerals could be determined more precisely, excluding organic matter. Based on the recorded results, curves for fraction contents were plotted, and grain-size index $\left(C_{u}\right)$ and grain-shape index $\left(C_{c}\right)$ were calculated.

Thus, collected data were implemented in a graphic computer program, in which the shape of the cross-sections was plotted. Flow velocity was determined using an ADCP StreamPro device [45], applying the phenomenon of sound wave propagation in the water environment. Measurement results were used to determine flow values and to plot river channel cross-sections; next, wetted perimeter $O$, hydraulic radius $R_{h}$, and water table gradient $I$ were calculated. At cross-section 2 , with dense tree and shrub cover, regular measurements were taken for LAI on both riverbanks. These measurements were recorded during the vegetation season using a LAI 2000 device. The results provided the basis for an assessment of area cover by the tree canopy (including leaves). In this manner information was obtained on the availability of light-reaching plants, including macrophytes, at the ground level.

In the next stage, model calculations for solar radiation were made in the ArcGIS environment. The input data for the analysis were the Digital Surface Model (DSM) (Figure 1a). The DSM model was developed on the basis of the LIDAR data. The DSM is characterized with spatial resolution of $1 \mathrm{~m}$ and was provided by the Head Office of Geodesy and Cartography, Poland. The DSM contains information concerning objects on the surface, such as vegetation and buildings, which are crucial for shading analysis. The area for analysis was extended to make sure all of the shadows cast on the riverbed were included in the calculations. Solar radiation was calculated using the Area Solar Radiation tool. The output of the tool was a global radiation raster calculated for the whole year, vegetation period, and separate months from April to September with a one-hour interval in $\mathrm{WH} \cdot \mathrm{m}^{-2}$. The results were assigned to the points of the cross-sections in the river.

\section{Results}

Results of flow measurements recorded using a miniature ADCP StreamPro flow meter were analyzed using the WinRiverII program. On this basis, values of flow, river bottom structure in the cross-sections, and the distribution of velocity were determined. Using the ADCP results and geodesy measures, graphs were prepared for the river cross-sections (Figure 3, Figure 4).

For the purpose of further calculations based on the above figures for each cross-section, their wetted perimeter, $O$, and cross-section, area $A$, were calculated. In the course of the measurements of water table ordinates, it was found that the water table gradient is so small that it is impossible to determine the slope at the river reach between the cross-sections. In order to determine slope, precise levelling was performed and the distance between the recorded measurements of water table height was increased to $380 \mathrm{~m}$. At the river reach of that length, the mean hydraulic gradient was $I=0.32 \%$. 


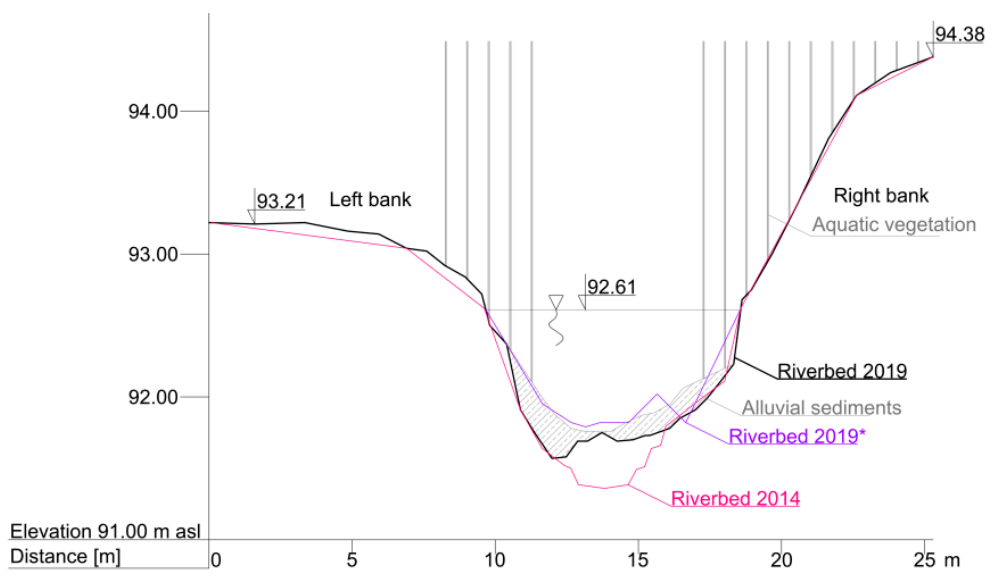

Figure 3. Bed changes in cross-section no. 1 (in an area with no tree cover-with submerged and emergent vegetation).

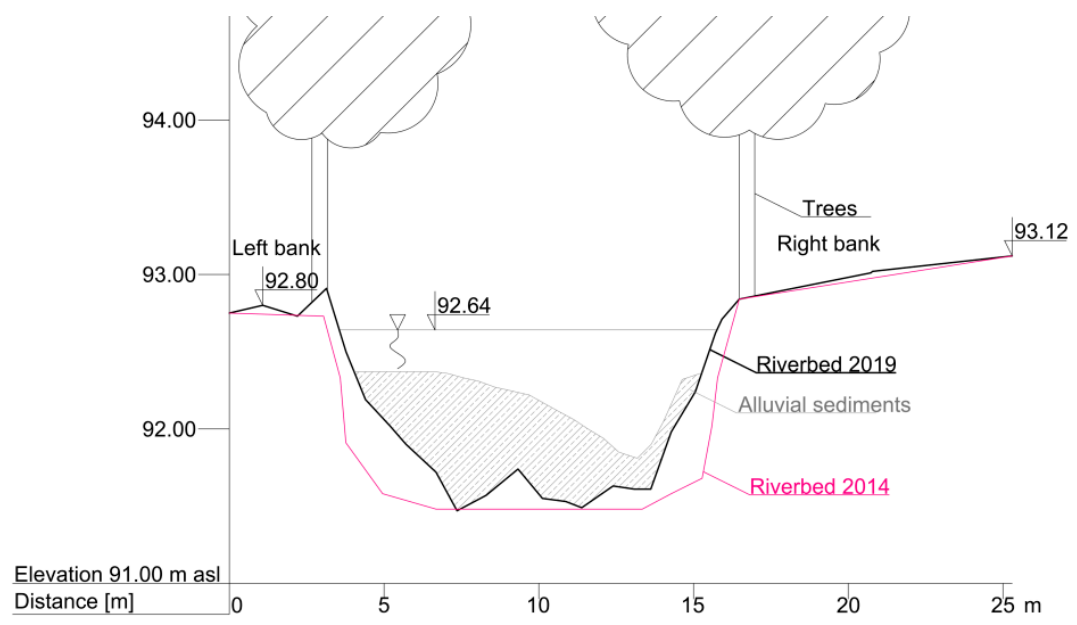

Figure 4. Bed changes in cross-section no. 2 (in a forested area).

In Figures 3 and 4 the cross-section was plotted for the status in 2014 and 2019. In the course of the study the cross-sections were also measured using a range pole. Cross-section 2 is wider, but slightly shallower than cross-section 1, in which, due to the bank overgrowth, flow is concentrated in the stream centerline of the watercourse. As a result of the large deposition of organic sediments the cross-sections measured using a range pole are slightly deeper (as they were probed to reach the so-called hard bottom). In this manner, the thickness of organic sediments deposited in the river channel could be assessed. Sediment thickness in cross-section 2 was much greater than in cross-section 1, with a maximum of $0.85 \mathrm{~m}$. In contrast, in cross-section 1, the sediment thickness did not exceed $0.4 \mathrm{~m}$. The analysis of the cross-sections also shows that within the previous five years channel shallowing was observed over the entire river reach. This trend is particularly evident in cross-section 2, where the bottom in the riverbank zone was elevated by as much as $0.6 \mathrm{~m}$. Also, in cross-section 1 channel shallowing by $0.4 \mathrm{~m}$ was recorded. River bottom elevation and shallowing of the cross-sections may be connected with small hydraulic gradients in the investigated river reach, which is reflected in small flow velocities, at mean values for both cross-sections ranging from $0.06 \mathrm{~m} / \mathrm{s}$ (cross-section 1 ) to $0.07 \mathrm{~m} / \mathrm{s}$ (cross-section 2).

This is related, among other things, to vegetation overgrowth in the river reach in the vicinity of cross-section 2, being the downstream measuring site for the investigated reach. Thus, in the reach the predominant processes are the accumulation of sediments, to a considerable extent composed of organic matter. 
A large proportion of the riverbank vegetation (trees and shrubs), i.e. those that are casting shadow over the entire river channel, causes shading, eliminating any aquatic vegetation within the river channel and banks. On the other hand, we may observe considerable accumulation of organic matter in the river reach. This also results from the small flow velocities. In cross-section 1, with the greatest share of riverbank and bottom vegetation, respective changes were observed in flow conditions. The flow velocity concentrates in the stream centerline zone, which also results in intensified erosion processes. This cross-section is the most compact.

Values of LAI were measured on the riverbanks at the tree-lined reach immediately above the ground. LAI is a measure for the total area of leaves per unit ground area, and it is directly related to the amount of light that can be intercepted by plants [44]. It is an important variable used to predict photosynthetic primary production and evapotranspiration, while it is also as a reference tool for crop growth. As such, LAI plays an essential role in theoretical production ecology. An inverse exponential relation has been established between LAI and light interception, which is linearly proportional to the primary production rate. Following the adopted methodology, the first measurement was taken in an open area with no vegetation (the reference measurement), while the next 12 were taken at the riverbanks, where trees and shrubs were found. For the right bank, the averaged LAI value was $3.03\left[\mathrm{~m}^{2} / \mathrm{m}^{2}\right]$, whereas for the left bank it was $3.06\left[\mathrm{~m}^{2} / \mathrm{m}^{2}\right]$. The values indicate dense overgrowth reducing access to light in the investigated cross-section.

In each of the cross-sections the river bottom was raked using garden rakes in order to identify species of the bottom vegetation. The belt of the raked river bottom was approximately $1 \mathrm{~m}$ wide. Plant samples were weighed using scales. For cross-section 1 the obtained plant sample was approximately $1.5 \mathrm{~kg}$. In cross-section 2 no bottom vegetation was found due to considerable shading. Samples of floating vegetation and plants growing on the banks were also collected. Identified plant species in the individual cross-sections are listed in Table 1.

Table 1. Plant species in individual sampling cross-sections.

\begin{tabular}{|c|c|c|c|c|c|c|}
\hline No. & $\begin{array}{c}2014 \\
\text { Bottom } \\
\text { Vegetation }\end{array}$ & $\begin{array}{c}\text { Floating } \\
\text { Vegetation }\end{array}$ & $\begin{array}{c}\text { Rush } \\
\text { Vegetation }\end{array}$ & $\begin{array}{c}2019 \\
\text { Bottom } \\
\text { Vegetation }\end{array}$ & $\begin{array}{l}\text { Floating } \\
\text { Vegetation }\end{array}$ & $\begin{array}{c}\text { Rush } \\
\text { Vegetation }\end{array}$ \\
\hline$P 1$ & $\begin{array}{l}\text { Potamogeton } \\
\text { pectinatus }\end{array}$ & $\begin{array}{l}\text { Hydrocharis } \\
\text { morsus-ranae L., } \\
\text { Spirodela } \\
\text { polyrhiza }\end{array}$ & $\begin{array}{l}\text { Sparganium } \\
\text { erectum, } \\
\text { Phragmites } \\
\text { australis }\end{array}$ & $\begin{array}{l}\text { Potamogeton } \\
\text { pectinatus, } \\
\text { Ceratophyllum } \\
\text { demersum L. }\end{array}$ & $\begin{array}{l}\text { Hydrocharis } \\
\text { morsus-ranae L., } \\
\text { Lemna minor L., } \\
\quad \text { Spirodela } \\
\text { polyrhiza }\end{array}$ & $\begin{array}{l}\text { Sparganium erectum, } \\
\text { Phragmites australis, } \\
\text { Typha latifolia L. } \\
\text { Typha angustifolia, L. } \\
\text { Humulus lupulus }\end{array}$ \\
\hline$P 2$ & no vegetation & no vegetation & $\begin{array}{l}\text { Sparganium } \\
\text { erectum }\end{array}$ & no vegetation & no vegetation & Sparganium erectum \\
\hline
\end{tabular}

Debris samples were collected from the river bottom. Substrate samples were subjected to sieve analysis in order to determine the grain-size composition. The sieve analysis was performed for samples from cross-sections 1 and 2 . On this basis the uniformity index $C_{u}$ was determined:

$$
C_{u}=\frac{d_{60}}{d_{10}}
$$

along with the curvature index $C_{c}$ :

$$
C_{c}=\frac{d_{30}^{2}}{d_{10} \cdot d_{60}}
$$

where: $d_{10}, d_{30}$ and $d_{60}$ are diameters of particles, which together with smaller ones, account for 10, 30, and $60 \%$ of soil mass, respectively (Table 2 ). 
Table 2. Debris parameters.

\begin{tabular}{ccccc}
\hline \multirow{2}{*}{ No. } & \multicolumn{2}{c}{2014} & \multicolumn{2}{c}{2019} \\
& $C_{u}[-]$ & $C_{c}[-]$ & $C_{u}[-]$ & $C_{c}[-]$ \\
\hline P1 & 3.02 & 0.91 & 2.29 & 0.86 \\
P2 & 2.51 & 1.83 & 2.39 & 0.84 \\
\hline
\end{tabular}

For cross-section P1 the uniformity index $C_{u}$ value classified the substrate as a grained substrate $\left(1 \leq C_{u} \leq 5\right)$. The curvature index $C_{c}$ indicates a poorly grained substrate. For cross-section P2 the recorded $C_{u}$ value corresponds to a uniformly grained substrate. The $C_{c}$ value corresponds to the values from the range for well-grained soils $\left(C_{c}=1-3\right)$. Results obtained after five years are similar and indicate a certain balance of river channel forming processes. Individual samples were incinerated in a furnace to determine organic matter content $(\mathrm{MO})$. The following results were recorded: cross-section P1-2.4\% MO (2014) and 4.1\% (2019); cross-section P2-26.5\% MO (2014) and 31.9\% (2019).

The percentage share of organic matter in the sample from cross-section P2 is considerably greater compared to the sample from cross-section P1. This results from the fact that sample 2 was collected from the cross-section, in which trees and shrubs were growing on both banks, while dying plant parts accumulated on the watercourse channel bottom. The increase of organic matter content after five years indicates intensive accumulation of organic substance in the investigated cross-sections of that river.

The mean roughness coefficient was obtained using the results of hydrometric and geodesy analyses, applying the Manning formula for individual cross-sections. The results for the calculations of measurements both from 2014 and 2019 are presented in Table 3. When field measurements were taken, the water table was found in the main river channel. In cross-section 1, aquatic vegetation was growing on the channel banks and the river bottom. Paradoxically, the values of the roughness coefficient for that cross-section are lower than those obtained for cross-section 2, in which no aquatic vegetation was found either on the bottom or in the bank zone. This results from the parameters of that cross-section (greater width) and the damming effect due to the cross-section with a high proportion of vegetation, found in the immediate vicinity. This results in a reduced flow velocity, which under the assumption of the constant averaged value of the hydraulic gradient provides a higher value of the roughness coefficient. The resulting roughness coefficients are typical of overgrown river channels, in which the presence of vegetation drastically reduces the flow capacity of the river channel (Table 3 ).

Table 3. Results of calculations of roughness coefficient.

\begin{tabular}{ccc}
\hline No. & $\begin{array}{c}\mathbf{2 0 1 4} \\
\mathbf{n}\left[\mathbf{m}^{-1 / 3} \cdot \mathbf{s}\right]\end{array}$ & $\begin{array}{c}\mathbf{2 0 1 9} \\
\mathbf{n}\left[\mathbf{m}^{-1 / 3} \cdot \mathbf{s}\right]\end{array}$ \\
\hline P1 & 0.090 & 0.139 \\
P2 & 0.156 & 0.188 \\
\hline
\end{tabular}

Solar radiation was calculated using the Area Solar Radiation tool in ArcGIS 10.5. The results were assigned to the points of the cross-sections of the river in the monthly configuration (Figure 5) as well as the vegetation period (Figure 6a) and annual configurations (Figure 6b).

Calculations showed that solar radiation in the annual period at cross-sections no. 1 and no. 2 amounted to $847 \times 10^{3}$ and $135 \times 10^{3} \mathrm{WH} \cdot \mathrm{m}^{-2}$, respectively (Table 4 ). In the analyzed river reach, total solar radiation varied, and ranged from $50 \times 10^{3}$ to $857 \times 10^{3} \mathrm{WH} \cdot \mathrm{m}^{-2}$. From point no. 11 , solar radiation was greater and ranged from 514 to $857 \times 10^{3} \mathrm{WH} \cdot \mathrm{m}^{-2}$ with the mean value of $743 \times 10^{3} \mathrm{WH} \cdot \mathrm{m}^{-2}$, which was connected with the exposure of the river channel. In the tree-lined river reach, total radiation ranged from 50 to $512 \times 10^{3} \mathrm{WH} \cdot \mathrm{m}^{-2}$ with the mean of $245 \times 10^{3} \mathrm{WH} \cdot \mathrm{m}^{-2}$. Results of calculations for individual months and the vegetation period are presented in Table 4 . The value of radiation in the period from April to September ranged from $38 \times 10^{3} \mathrm{WH} \cdot \mathrm{m}^{-2}$ at point 
no. 6 to $687 \times 10^{3} \mathrm{WH} \cdot \mathrm{m}^{-2}$ at point no. 13. In cross-section no. 2 , monthly values of solar radiation in the period from April to September ranged from 14 to $21 \times 10^{3} \mathrm{WH} \cdot \mathrm{m}^{-2}$ at the total value of $110 \times 10^{3} \mathrm{WH} \cdot \mathrm{m}^{-2}$. In turn, in cross-section no. 1 solar radiation in individual months was almost fiveto over eightfold higher, with a mean of over sixfold higher. Greater insolation in cross-section no. 1 contributed to more intensive growth of river channel vegetation.

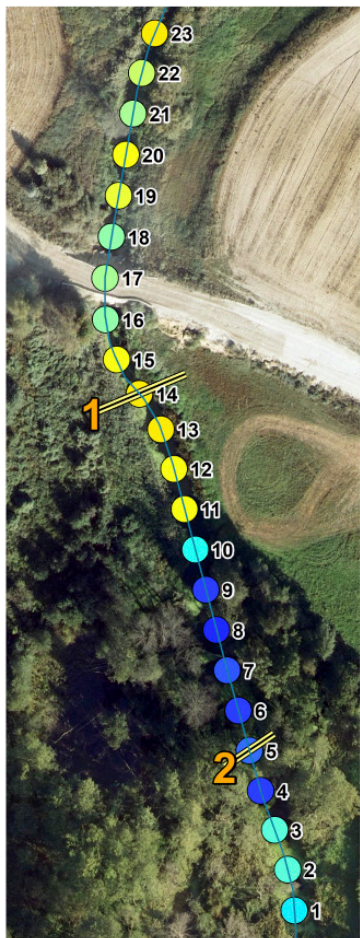

April

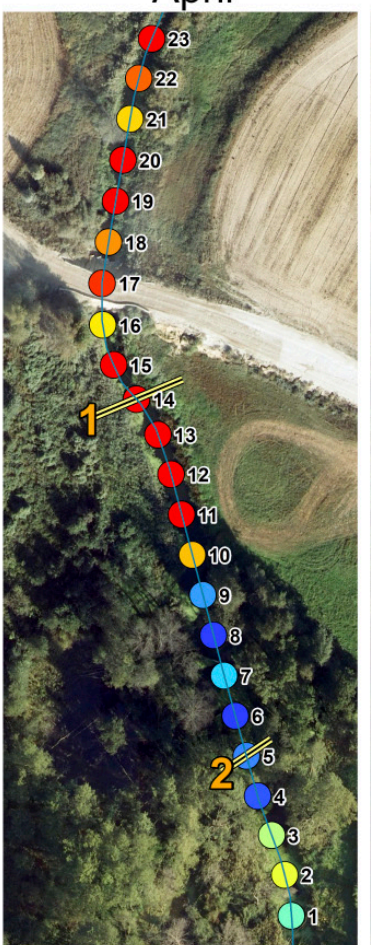

July

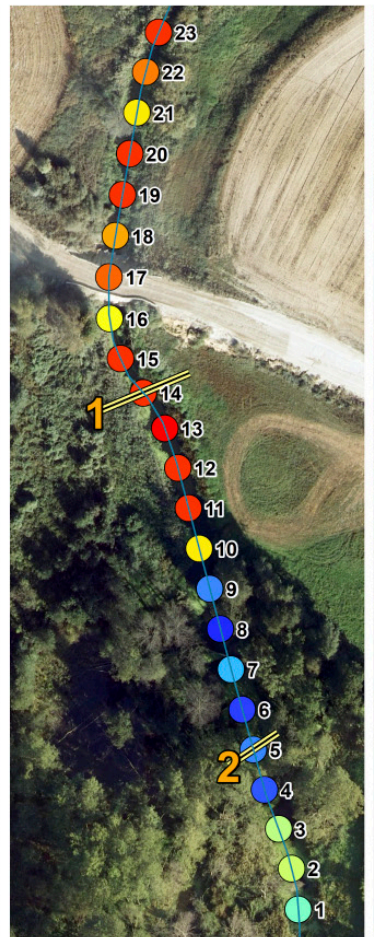

May

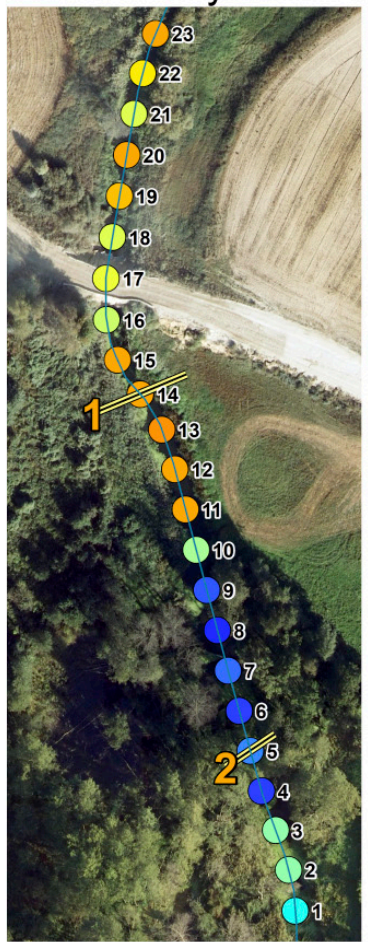

August

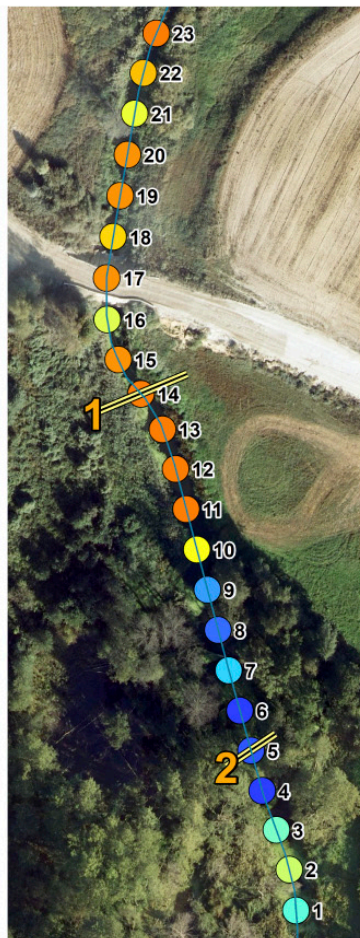

June

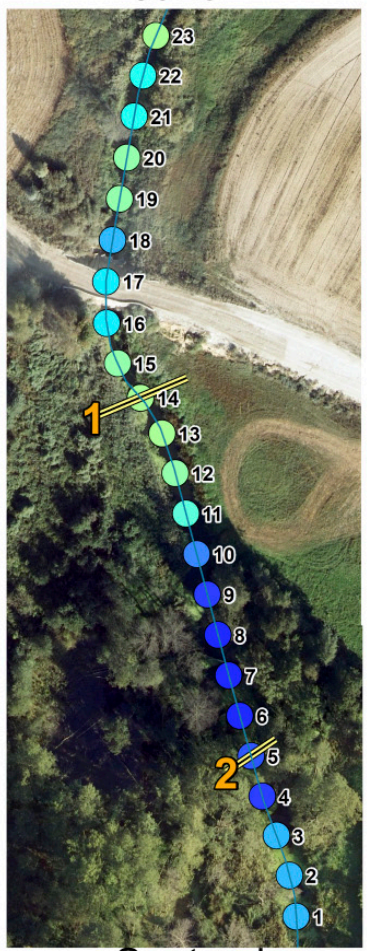

September
Solar Radiation

$\mathrm{WH} / \mathrm{m}^{2}$

2000

2001-5000

$5001-10000$

$10001-15000$

$15001-20000$

$20001-25000$

$25001-30000$

$30001-35000$

$35001-40000$

40001 - 45000

$45001-50000$

$50001-55000$

$55001-60000$

$60001-65000$

$65001-70000$

$70001-75000$

$75001-80000$

$80001-85000$

85001 - 90000

$90001-95000$

$95001-100000$

$100001-105000$

$105001-110000$

$110001-115000$

$115001-120000$

$120001-125000$

$125001-130000$

130001- 135000

$135001-140000$

$140001-145000$

Ecross section

-stream centerline

$0 \quad 1020 \mathrm{~m}$
$\sim$

Figure 5. Distribution of total solar radiation $\left(\mathrm{WH} \cdot \mathrm{m}^{-2}\right)$ reaching the substrate in the analyzed Wełna River reach in individual months. 

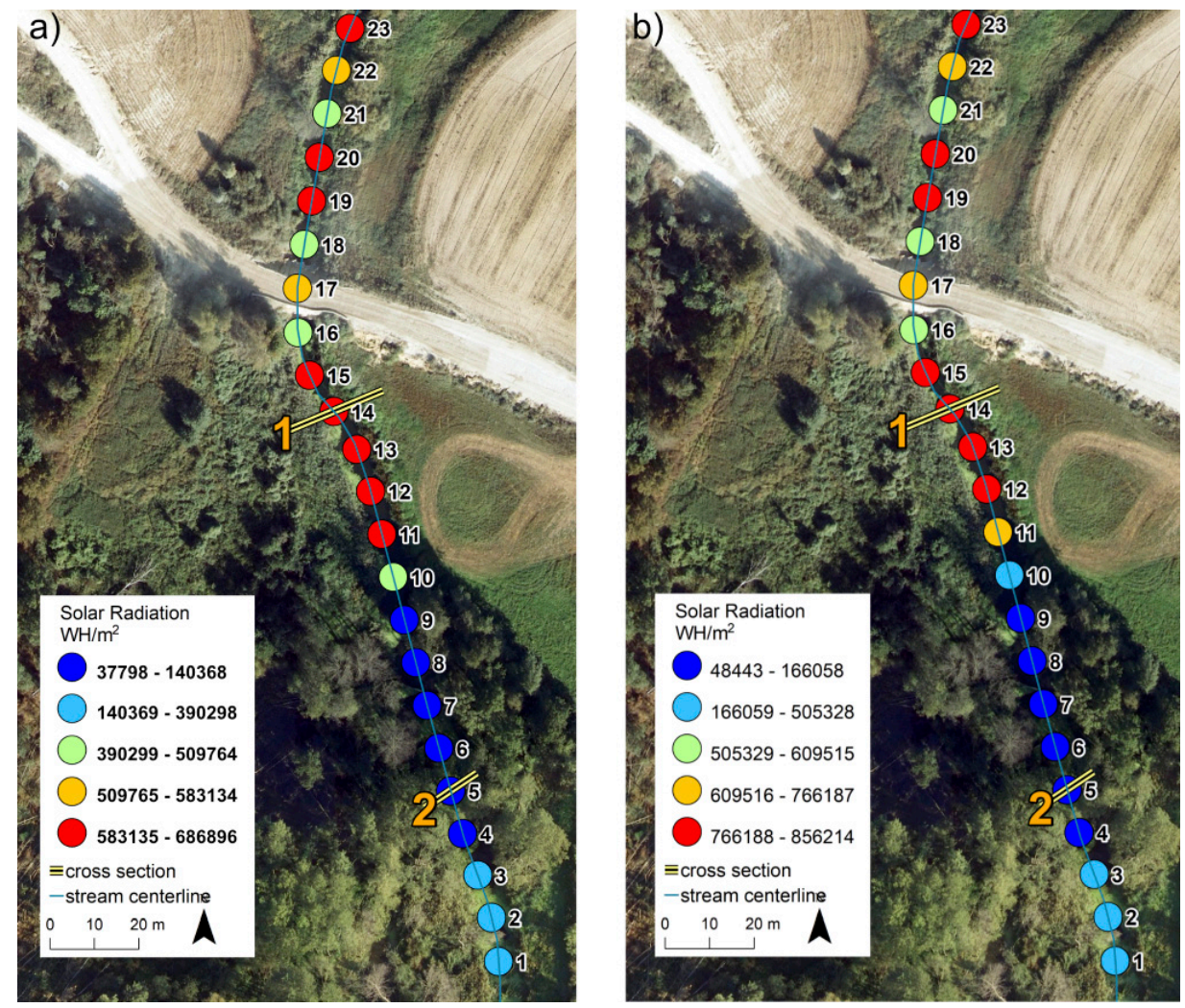

Figure 6. Distribution of total solar radiation $\left(\mathrm{WH} \cdot \mathrm{m}^{-2}\right)$ reaching the substrate in the investigated reach of the Wełna River for: (a) the period of April-September, (b) the annual period.

Table 4. Solar radiation $\left(10^{3} \cdot \mathrm{WH} \cdot \mathrm{m}^{-2}\right)$ at points located along the investigated reach of the Wełna River.

\begin{tabular}{cccccccc}
\hline No. & April & May & June & July & August & September & April-September \\
\hline 1 & 42 & 58 & 55 & 59 & 49 & 31 & 293 \\
2 & 52 & 78 & 80 & 85 & 63 & 32 & 390 \\
3 & 52 & 70 & 59 & 71 & 60 & 32 & 344 \\
4 & 7 & 10 & 8 & 10 & 9 & 5 & 50 \\
$5(\mathrm{P} 2)$ & 19 & 21 & 15 & 20 & 21 & 14 & 110 \\
6 & 5 & 7 & 8 & 8 & 6 & 4 & 38 \\
7 & 11 & 33 & 36 & 38 & 19 & 4 & 140 \\
8 & 3 & 4 & 18 & 7 & 3 & 2 & 38 \\
9 & 10 & 20 & 26 & 26 & 12 & 7 & 101 \\
10 & 47 & 99 & 93 & 106 & 69 & 21 & 434 \\
11 & 91 & 137 & 120 & 142 & 112 & 51 & 652 \\
12 & 95 & 138 & 122 & 143 & 113 & 64 & 675 \\
13 & 97 & 140 & 123 & 145 & 115 & 67 & 687 \\
$14(\mathrm{P} 1)$ & 95 & 138 & 121 & 143 & 113 & 65 & 677 \\
15 & 95 & 136 & 119 & 140 & 112 & 65 & 666 \\
16 & 63 & 92 & 81 & 96 & 75 & 43 & 451 \\
17 & 68 & 127 & 117 & 137 & 88 & 45 & 583 \\
18 & 62 & 110 & 103 & 119 & 81 & 35 & 510 \\
19 & 90 & 135 & 120 & 141 & 108 & 61 & 655 \\
20 & 94 & 136 & 119 & 141 & 112 & 63 & 665 \\
21 & 68 & 99 & 87 & 103 & 81 & 46 & 483 \\
22 & 79 & 121 & 109 & 126 & 97 & 46 & 579 \\
23 & 96 & 139 & 122 & 144 & 114 & 65 & 680 \\
\hline
\end{tabular}




\section{Discussion}

The obtained results indicate the importance of shading for macrophyte growth. Similarly, as in a study by Jusik and Staniszewski [17], it was shown that increased shading perhaps limited macrophyte biodiversity and total cover in the river channels. The development of aquatic plants in the river channels is limited by shading [23]. Ali et al. [23] suggested that the management of tree vegetation might control incoming solar radiation, affecting submerged macrophytes. Similarly to the present case study, other studies shown that the impact of trees on the growth of aquatic plants depends on the group of macrophytes and the range of shadow impact [18,46]. Also, Jusik and Szoszkiewicz [47] observed significant correlations between the level of morphological modifications and shadowing of lowland river channels. Together with the increase in modifications of watercourses, the rate of shadowing decreased due to the changes of land use and simplification of the riparian species structure, commonly related to river regulation works. Kurtz et al. [48] conducted a shading experiment over a vegetation period to measure the effects of light reduction on Vallisneria americana in Perdido Bay (Florida-Alabama). The results showed that a 92\% light reduction led to a decrease in chlorophyll a concentration, biomass, and leaf dimensions of macrophytes. Schneider et al. [49] showed that submerged macroscopic algae (Chara intermedia and C. contraria), which grow in an upright position, are taller at higher light intensities. In turn, Tan et al. [50] showed that reduced light reduced the growth of M. aquaticum; all of the analyzed growth indicators were significantly higher in sunlight treatment compared to the shading treatments. Kankanamge et al. [51] observed differences in shade tolerance between native and non-native species. In high shade ( $\geq 90 \%)$, the reduction in lateral spread and an increase in main stem length for non-native macrophytes was observed, while native species showed no response for these traits.

The river's shading is spatially and temporally heterogeneous. Spatial variations are related to landscape (channel width, orientation, and hillshade) and canopy characteristics (canopy extent, structure, and height) [41,52]. Temporal variations are related to temporal variability of canopy structure and sun position in terms of days, months, and years [42]. As it was shown in this study, only the use of a suitable model allows reliable assessment of the amount of energy reaching the ground.

During the planning of river conservation or regulation works, it is crucial to maintain proper light conditions for macrophytes in view of the potential problems with both absence and limitation of aquatic plant development [4]. Excess light, which can even cause full overgrowth of the river channel, respectively changes water flow conditions [34] and causes a decrease in channel permeability [14]. The phenomenon of river channel overgrowth is very intensive in lowland rivers flowing through agricultural areas [16], with the simultaneous presence of strong sunlight conditions (lack of trees, removed during regulation works) and significant input of nutrients due to the surface flow [14].

Flow resistance for a specific type of aquatic vegetation is a function of many variables, including flow velocity, plant shape (habit), and roughness of the river bottom and channel walls. In recent decades hydraulic flow conditions in open river channels overgrown with vegetation have been investigated by many research centers $[7,53,54]$. Similarly, as in the present study, most research on the subject has been experimental $[55,56]$. For example, the authors of numerous papers analyzed flow conditions in overgrown river channels at an increase in the roughness coefficient [57] or in terms of changes in debris transport processes [55]. Many papers also indicate the need to combine the stream transport capacity with the degree of shading of the cross-section by aquatic vegetation [58]. In literature on the subject [58], an association was noted between the degree of cross-section shading by vegetation and values of the roughness coefficient, and biomass of aquatic plants [57]. Similarly, as in the case of these results, Łoboda et al. [59] showed that the presence of plants within the river channel cross-section slightly reduces the cross-section surface area, but markedly changes the distribution of flow velocity. This observation was also confirmed by studies on the effect of river channel dredging on values of the roughness coefficient and distributions of velocity $[57,60]$. 
In a similar way as by Przyborowski et al. [61], results obtained in this study may be referred to hydromorphological changes, in the analyzed case connected with transport and sedimentation of fine organic particles. The presence of plants has a considerable effect on the above-mentioned processes.

Calculations conducted according to the method proposed by Rickert [36] for the location at $\varphi=52.5^{\circ}$ northern latitude (comparable to the location of the reach in Coton with ordinates $52.678^{\circ} \mathrm{N}$ $\left.17.631^{\circ} \mathrm{E}\right)$ for the cross-section shaded by trees showed that the actual solar radiation reaching the water surface decreases within 24-hour periods to values comparable to those obtained in the model for the shaded river reach. The values of total photosynthetically active radiation for the shaded river reach confirmed a lack of potential conditions for hydrophyte growth in that part of the river reach.

\section{Conclusions}

This paper presents an example of studies on the effect of factors causing watercourse channel shading on water flow conditions and the dynamics of hydromorphological processes. The presented analysis indicates the importance of local conditions determining availability of light energy for plants on the hydromorphological conditions found in a watercourse. The selected reach of the Wełna River is characterized by high variability in river channel shading, resulting from the presence of a dense forest complex growing in the upstream river stretch $(\mathrm{LAI}=3)$. Immediately outside the forest edge, the river flows among meadows and arable fields, where there are no trees. These conditions affect river channel morphology and flow conditions. In the forested river reach, bottom and riverbank vegetation is completely absent. The river channel is wide; however, because of the vicinity of trees and shrubs, considerable accumulation of organic matter is observed in the river channel $(26.5 \% \mathrm{MO}$ compared to $2.4 \% \mathrm{MO}$ in the treeless cross-section in 2014, and $31.9 \% \mathrm{MO}$ to $4.1 \%$ in 2019 ). This is also promoted by the very low flow velocity (approximately $0.1 \mathrm{~m} / \mathrm{s}$ ). This velocity results from the damming effect as a result of overgrowth in the river reach located immediately outside the forest. The downstream reach is characterized by a large amount of vegetation overgrowing the banks and the river bottom. This cross-section is more compact, and flow velocities in the streamline are slightly higher (although with reference to the entire cross-section together with the vegetation (dead) zones the mean velocity is also approximately $0.1 \mathrm{~m} / \mathrm{s}$ ). The developed model of light availability makes it possible to determine river channel overgrowth conditions, and thus to predict potential dynamics of hydrodynamic processes. Analysis of total radiation reaching the water surface through trees, ranging from 50 to $512 \times 10^{3} \mathrm{WH} \cdot \mathrm{m}^{-2}$ at the mean value of $245 \times 10^{3} \mathrm{WH} \cdot \mathrm{m}^{-2}$, confirmed a significant role of shading, as limiting macrophyte growth, which in turn causes changes in the character of hydromorphological processes.

Author Contributions: Conceptualization, T.K.; methodology, T.K. and R.W.; validation, T.K., S.Z. and M.H.; investigation, T.K., S.Z. and M.H.; writing-original draft preparation, T.K., M.S., R.W., J.J., S.Z. and M.H.; writing-review and editing, T.K., M.S. and J.J.; visualization, S.Z. and R.W.; supervision, T.K. and M.S.; project administration, T.K. All authors have read and agreed to the published version of the manuscript.

Funding: The publication was co-financed within the framework of the Ministry of Science and Higher Education program "Regional Initiative Excellence" in the years 2019-2022, Project No. 005/RID/2018/19.

Conflicts of Interest: The authors declare no conflict of interest.

\section{References}

1. Angelopoulos, N.V.; Cowx, I.G.; Buijse, A.D. Integrated planning framework for successful river restoration projects: Upscaling lessons learnt from European case studies. Environ. Sci. Policy 2017, 76, 12-22. [CrossRef]

2. Kałuża, T.; Pietruczuk, K.; Szoszkiewicz, K.; Tymiński, T. Assessment and classification of the ecological status of rivers in Poland according to the requirements of the water framework directive. Wasserwirtsch. Wassertech. 2014, 104, 24-29. [CrossRef]

3. Birk, S.; Willby, N. Towards harmonization of ecological quality classification: Establishing common grounds in European macrophyte assessment for rivers. Hydrobiologia 2010, 652, 149-163. [CrossRef] 
4. Hachoł, J.; Bondar-Nowakowska, E. An assessment of the ecological status of diverse watercourses of Lower Silesia, Poland. Pol. J. Environ Stud. 2012, 21, 75-81.

5. Hajdukiewicz, H.; Wyżga, B.; Zawiejska, J.; Amirowicz, A.; Oglecki, P.; Radecki-Pawlik, A. Assessment of river hydromorphological quality for restoration purposes: An example of the application of RHQ method to a Polish Carpathian river. Acta Geophys. 2017, 65, 423-440. [CrossRef]

6. Wiegleb, G.; Herr, B.; Zander, B.; Bröring, U.; Brux, H.; Van De Weyer, K. Natural variation of macrophyte vegetation of lowland streams at the regional level. Limnologica 2015, 51, 5362. [CrossRef]

7. Laks, I.; Sojka, M.; Walczak, Z.; Wróżyński, R. Possibilities of using low quality digital elevation models of floodplains in hydraulic numerical models. Water 2017, 9, 283. [CrossRef]

8. Mazur, R.; Kałuża, T.; Chmist, J.; Walczak, N.; Laks, I.; Strzeliński, P. Influence of deposition of fine plant debris in river floodplain shrubs on flood flow conditions- The Warta River case study. Phys. Chem. Earth. 2016, 94, 106-113. [CrossRef]

9. Vermaat, J.E.; Van Viersen, W. Growth potential for weeds in rivers. H2O 1990, 23, 534-536.

10. Walczak, N.; Walczak, Z.; Kałuża, T.; Hämmerling, M.; Stachowski, P. The impact of shrubby floodplain vegetation growth on the discharge capacity of river valleys. Water 2018, 10, 556. [CrossRef]

11. Szałkiewicz, E.; Dysarz, T.; Kałuża, T.; Malinger, A.; Radecki-Pawlik, A. Analysis of in-stream restoration structures impact on hydraulic condition and sedimentation in the Flinta River, Poland. Carpathian J. Earth Env. 2019, 14, 275-286. [CrossRef]

12. Laks, I.; Kałuża, T.; Sojka, M.; Walczak, Z.; Wróżyński, R. Problems with modelling water distribution in open channels with hydraulic engineering structures. Annu. Set Environ. Prot. 2013, 15, 245-257.

13. Mikuś, P.; Wyżga, B.; Radecki-Pawlik, A.; Zawiejska, J.; Amirowicz, A.; Oglęcki, P. Environment-friendly reduction of flood risk and infrastructure damage in a mountain river: Case study of the Czarny Dunajec. Geomorphology 2016, 272, 43-54. [CrossRef]

14. Dawson, F.H. The reduction of light as a technique for the control of aquatic plants an assessment. In Proceedings of the Association of Applied Biologists Symposium Aquatic Weeds and their Control, Oxford, UK, 7-8 April 1981.

15. Ptak, M.; Sojka, M.; Kałuża, T.; Choiński, A.; Nowak, B. Long-term water temperature trends of the Warta River in the years 1960-2009. Ecohydrol. Hydrobiol. 2019, 19, 441-451. [CrossRef]

16. Burrell, T.K.; O’Brien, M.; Graham, S.E.; Simon, K.S.; Harding, J.S.; Mcintosh, A.R. Riparian shading mitigates stream eutrophication in agricultural catchments. Freshw. Sci. 2014, 33, 73-84. [CrossRef]

17. Jusik, S.; Staniszewski, R. Shading of river channels as an important factor reducing macrophyte biodiversity. Pol. J. Environ. Stud. 2019, 28, 1215-1222. [CrossRef]

18. Sender, J. The effect of riparian forest shade on the structural characteristics of macrophytes in a mid-forest lake. Appl. Ecol. Env. Res. 2016, 14, 249-261. [CrossRef]

19. Szoszkiewicz, K.; Ferreira, T.; Korte, T.; Baattrup-Pedersen, A.; Davy-Bowker, J.; O’Hare, M. European river plant communities: The importance of organic pollution and the usefulness of existing macrophyte metrics. Hydrobiologia 2006, 566, 211-234. [CrossRef]

20. Radecki-Pawlik, A.; Kuboń, P.; Radecki-Pawlik, B.; Plesiński, K. Bed-load transport in two different-sized mountain catchments: Mlynne and Lososina streams, Polish Carpathians. Water 2019, 11, 272. [CrossRef]

21. Pedersen, M.L.; Baatrup-Pedersen, A.; Roth, F.R.; Madsen, T.V.; Larsen, S.E. Short-term impacts of weed cutting on physical habitats in lowland rivers-The importance of initial environmental conditions. Pol. J. Environ. Stud. 2011, 20, 1271-1280.

22. Szoszkiewicz, K.; Zbierska, J.; Staniszewski, R.; Jusik, S. The variability of macrophyte metrics used in river monitoring. Oceanol. Hydrobiol. Stud. 2009, 38, 117-126. [CrossRef]

23. Ali, M.M.; Hassan, S.A.; Shaheen, A.S.M. Impact of riparian trees shade on aquatic plant abundance in conservation islands. Acta Bot. Croat. 2011, 70, 245-258. [CrossRef]

24. Schooler, S. Shade as a management tool for the invasive submerged macrophyte, Cabomba caroliniana. J. Aquat. Plant Manag. 2008, 46, 168-171.

25. Abernethy, V. Response of Elodea canadensis Michx and Myriophyllum spicatum L. to shade, cutting and competition in experimental culture. Hydrobiologia 1996, 340, 219-224. [CrossRef]

26. Dawson, F.H. Water flow and vegetation of running waters. In Vegetation of Inland Waters; Symoens, J.J., Ed.; Kluwer Dordrecht/Junk: The Hague, The Netherlands, 1988. [CrossRef] 
27. Kohler, J.; Hachoł, J.; Hilt, S. Regulation of submersed macrophyte biomass in a temperate lowland river: Interactions between shading by bank vegetation, epiphyton and water turbidity. Aquat. Bot. 2010, 92, 129-136. [CrossRef]

28. Wersal, R.M.; Madsen, J.D. Influences of light intensity variations on growth characteristics of Myriophyllum aquaticum. J. Freshw. Ecol. 2013, 28, 147-164. [CrossRef]

29. Lin, Y.; Herold, M. Tree species classification based on explicit tree structure feature parameters derived from static terrestrial laser scanning data. Agric. For. Meteorol. 2016, 216, 105-114. [CrossRef]

30. Wilcock, R.J.; Scarsbrook, M.R.; Cooke, J.G.; Costley, K.J.; Nagels, J.W. Shade and flow effects on ammonia retention in macrophyte-rich streams: Implications for water quality. Environ. Pollut. 2004, 132, 95-100. [CrossRef]

31. Zefferman, E. Increasing canopy shading reduces growth but not establishment of Elodea nuttallii and Myriophyllum spicatum in stream channels. Hydrobiologia 2014, 734, 159-170. [CrossRef]

32. Kałuża, T.; Sojka, M.; Strzeliński, P.; Wróżyński, R. Application of terrestrial laser scanning to tree trunk bark structure characteristics evaluation and analysis of their effect on the flow resistance coefficient. Water 2018, 10, 753. [CrossRef]

33. Lu, J.; Wang, Z.; Xing, W.; Liu, G. Effects of substrate and shading on the growth of two submerged macrophytes. Hydrobiologia 2013, 700, 157-167. [CrossRef]

34. Kałuża, T. The influence of the trees and bushes shadow on the changes of flow conditions in the lowland watercourse. Acta Sci. Pol. Form. Circumiectus 2015, 14, 29. [CrossRef]

35. Dysarz, T.; Szałkiewicz, E.; Wicher-Dysarz, J. Long-Term impact of sediment deposition and erosion on water surface profiles in the Ner River. Water 2017, 9, 168. [CrossRef]

36. Rickert, K. Der Einfluss von Gehölz auf die Lichtverhältnisse und das Abflussverhalten in Fließgewässern. Mitteilungen des Instituts für Wasser-wirtschaft, Hydrologie und landwirtsch Wasserbau der Univesität Hannover: Hannover, Germany, 1986.

37. Bode, C.A.; Limm, M.P.; Power, M.E.; Finlay, J.C. Subcanopy solar radiation model: Predicting solar radiation across a heavily vegetated landscape using LiDAR and GIS solar radiation models. Remote Sens. Environ. 2014, 154, 387-397. [CrossRef]

38. Johnson, M.F.; Wilby, R.L. Seeing the landscape for the trees: Metrics to guide riparian shade management in river catchments. Water Resour. Res. 2015, 51, 3754-3769. [CrossRef]

39. Wawrzyniak, V.; Allemand, P.; Bailly, S.; Lejot, J.; Piégay, H. Coupling LiDAR and thermal imagery to model the effects of riparian vegetation shade and groundwater inputs on summer river temperature. Sci. Total Environ. 2017, 592, 616-626. [CrossRef]

40. Loicq, P.; Moatar, F.; Jullian, Y.; Dugdale, S.J.; Hannah, D.M. Improving representation of riparian vegetation shading in a regional stream temperature model using LiDAR data. Sci. Total Environ. 2018, 624, 480-490. [CrossRef]

41. Karrasch, P.; Hunger, S. Simulation of vegetation and relief induced shadows on rivers with remote sensing data. Proceedings of Earth Resources and Environmental Remote Sensing/GIS Applications VIII, Warsaw, Poland, 5 October 2017.

42. Bachiller-Jareno, N.; Hutchins, M.G.; Bowes, M.J.; Charlton, M.B.; Orr, H.G. A novel application of remote sensing for modelling impacts of tree shading on water quality. J. Environ. Manag. 2019, 230, $33-42$. [CrossRef]

43. Environment Agency. Keeping Rivers Cool: Getting Ready for Climate Change by Creating Riparian Shade; Environment Agency Horizon House: Bristol, UK, 2012.

44. Houborg, R.; McCabe, M.F. Daily Retrieval of NDVI and LAI at $3 \mathrm{~m}$ resolution via the fusion of CubeSat, Landsat, and MODIS Data. Remote Sens. 2018, 10, 890. [CrossRef]

45. Lee, K.; Ho, H.C.; Marian, M.; Wu, C.H. Uncertainty in open channel discharge measurements acquired with StreamPro ADCP. J. Hydrol. 2014, 509, 101-114. [CrossRef]

46. Zhu, Z.; Song, S.; Yan, Y.; Li, P.; Jeelani, N.; Wang, P.; An, S.; Leng, X. Combined effects of light reduction and ammonia nitrogen enrichment on the submerged macrophyte Vallisneria natans. Mar. Freshw. Res. 2018, 69, 764-770. [CrossRef]

47. Jusik, S.; Szoszkiewicz, K. Biodiversity of water plants in diverse conditions of morphological modifications in lowland rivers of western Poland. Nauka Przyroda Technologie 2009, 3, 84. 
48. Kurtz, J.C.; Yates, D.F.; Macauley, J.M.; Quarles, R.L.; Genthner, F.J.; Chancy, C.A.; Devereux, R. Effects of light reduction on growth of the submerged macrophyte Vallisneria americana and the community of root-associated heterotrophic bacteria. J. Exp. Mar. Biol. Ecol. 2003, 291, 199-218. [CrossRef]

49. Schneider, S.C.; Pichler, D.E.; Andersen, T.; Melzer, A. Light acclimation in submerged macrophytes: The roles of plant elongation, pigmentation and branch orientation differ among Chara species. Aquat. Bot. 2015, 120, 121-128. [CrossRef]

50. Tan, B.C.; He, H.; Gu, J.; Li, K.Y. Effects of nutrient levels and light intensity on aquatic macrophyte (Myriophyllum aquaticum) grown in floating-bed platform. Ecol. Eng. 2019, 128, 27-32. [CrossRef]

51. Kankanamge, C.E.; Matheson, F.E.; Riis, T. Shading constrains the growth of invasive submerged macrophytes in streams. Aquat. Bot. 2019, 158, 103125. [CrossRef]

52. Li, G.; Jackson, C.R.; Kraseski, K.A. Modeled riparian stream shading: Agreement with field measurements and sensitivity to riparian conditions. J. Hydrol. 2012, 428, 142-151. [CrossRef]

53. Antonarakis, A.S.; Richards, K.S.; Brasington, J.; Muller, E. Determining leaf area index and leafy tree roughness using terrestrial laser scanning. Water Resour. Res. 2010, 46. [CrossRef]

54. Laks, I.; Szoszkiewicz, K.; Kałuża, T. Analysis of in situ water velocity distributions in the lowland river floodplain covered by grassland and reed marsh habitats-A case study of the bypass channel of Warta River (Western Poland). J. Hydrol. Hydromech. 2017, 65, 325-332. [CrossRef]

55. Przyborowski, Ł.; Łoboda, A.M.; Bialik, R.J. Experimental Investigations of Interactions between Sand Wave Movements, Flow Structure, and Individual Aquatic Plants in Natural Rivers: A Case Study of Potamogeton pectinatus L. Water 2018, 10, 1166. [CrossRef]

56. Przyborowski, Ł.; Łoboda, A.M.; Karpiński, M.; Bialik, R.J. Characteristics of flow around aquatic plants in natural conditions: Experimental setup, challenges and difficulties. In Free Surface Flows and Transport Processes; Kalinowska, M.B., Mrokowska, M.M., Rowiński, P.M., Eds.; Springer: Cham, Switzerland, 2018; pp. 347-361. [CrossRef]

57. Kenel, B.; Uehlinger, U. Effects of plant cutting and dredging on habitat conditions in streams. Arch. Hydrobiology 1998, 143, 257-273. [CrossRef]

58. Querner, E.P. A model to estimate timing of aquatic weed control in drainage canals. Irrig. Drain. Syst. 1997, 11, 157-169. [CrossRef]

59. Łoboda, A.M.; Bialik, R.J.; Karpiński, M.; Przyborowski, Ł. Two simultaneously occurring Potamogeton species: Similarities and differences in seasonal changes of biomechanical properties. Pol. J. Environ Stud. 2019, 28, 237-253. [CrossRef]

60. Tymiński, T. Hydraulic Model Investigation of Flow Conditions for Floodplains with Coniferous and Deciduous Shrubs. Pol. J. Environ Stud. 2012, 21, 1047-1052.

61. Przyborowski, Ł.; Łoboda, A.M.; Bialik, R.J.; Västilä, K. Flow field downstream of individual aquatic plants -Experiments in a natural river with Potamogeton crispus L. and Myriophyllum spicatum L. Hydrol. Processes 2019, 33, 1324-1337. [CrossRef]

(C) 2020 by the authors. Licensee MDPI, Basel, Switzerland. This article is an open access article distributed under the terms and conditions of the Creative Commons Attribution (CC BY) license (http://creativecommons.org/licenses/by/4.0/). 